which are made to new crematories by the daily press of this country and Europe. In France a very important advance has been made, as the prefecture of the Seine has decided to spend $\$ 40,000$ for a crematorium in the great Parisian cemetery, Pêre Lachaise. Dr. G. Pini has recently published a book on 'La cremation en Italie à l'étranger de 1774 jusqu'à nos jours,' which shows that in Italy but little progress had been made until the cremation of the body of Albert Keller on the 22d of January, 1876, about which time a society of three hundred was organized at Milan, which published a circular giving urgent reasons for the practice. Thirty-one societies existed at the date of publication of Dr. Pini's work, in the principal cities of Italy, and 394 bodies had been submitted to disposal by fire in the crematories erected by those societies, mainly in Milan, Lodi, Brescia, and Rome. More than three-fourths of this number were cremated at Milan. The chief point worthy of comment in the present law relative to the Society of Milan, is its method of dealing with the only valid objection which has ever been urged against cremation ; namely, the possible concealment of crime. The clause in question reads as follows: "If the cause of death is 'incertaine, suspecte, imprévue, ou violente,' the cremation of the body must be preceded by an autopsy." In this country a pamphlet has recently been published by the Worcester, Mass., cremation society, written by Dr. Marble. His argument might fitly be named, as he states, 'The dangers of earth-burial.' He cites many instances to prove that the graveyard is an objectionable institution for sanitary reasons. Chief among the resulting evils he places the pollution of watersupplies. A Massachusetts act was passed in 1885, authorizing the formation of societies for cremating the dead, and contains a provision for the prevention of the concealment of crime similar to that in force in Milan.

\section{RAILROAD TO MERV, BOKHARA, AND SAMARKAND.}

WHILE the attention of the world has been engaged upon the Servian-Bulgarian disputes, the Russian engineers have been pushing on the TransCaspian railroad, and transforming this mysterious Asia into a Russian province. This road, one of the wonders of our age, which commences at the Caspian Sea, is already opened three hundred and eighty kilometres, to within eighty kilometres of
Askabad, and was to be opened to that place in December, 1885.

The grading of the road is finished to Dushak, one hundred and fifty kilometres south-east of Askabad. At this point the road will branch. The Indian branch will be built to Saraks, about two hundred kilometres, where it will connect with the English road from Quetta, through Afghanistan, making the great road to India. The other branch will run north-east into central Asia, crossing the Amu Daria, and running through Bokhara to Samarkand.

This line has been commenced, but it will take at least three years to complete it. It passes through Merv, and will be finished to that place next spring. From the Caspian Sea to Merv is about six hundred kilometres, and thence to the river $\mathrm{Amu}$ Daria is about five hundred kilometres.

The road to Dushak crosses a small portion of the Great Desert from the Caspian Sea, about one hundred kilometres, to the great range of mountains that separate Persia from Turkestan, thence along the foot of this range of mountains, through a tolerably well-watered region, to Dushak. Here it crosses the steppes of the Great Desert, towards those broad plains whence Attila, Genghis Khan, and Tamerlane led forth their armies to overrun Europe.

All the materials for the railroad, even the wood for its construction, come from the interior of Russia. Some of the workmen come from beyond Smolensk in Russia, near the borders of Poland; others are the war-like Tekkes and Turkomans, of whom nearly eight thousand have been employed upon the road; while more are seeking employment than are required.

The horses are purchased in the steppes of Kirghiz, one thousand kilometres east from Merv, while their drivers are the Cossacks from the district of the Don, two thousand kilometres west.

Water, which is wanting almost everywhere in these vast steppes, is collected in the oases. It is frequently muddy and sometimes salt, and is then purified by powerful filters, and pumped through pipes, which furnish it to the laborers, thirty kilometres distant. Coal and wood for fuel are wanting; but petroleum has been discovered in almost unlimited quantities, and is used for locomotives and steamers.

The Russian colony lives in ambulant villages, moving along as the work progresses, carrying with it the commissariat, stores, and offices, and a collection of such articles as may be required for the work or the workmen. The telegraph precedes the railroad; and already Merv, Samarkand, and Bokhara are connected by wires with 
St. Petersburg, and thus civilization is carried to the oldest of the Aryan tribes.

The Russian merchants are opening warehouses along the line of the railroad, and supplying the inhabitants of the desert on the north, to Khiva, Bokhara, and Samarkand, and the Persians to the south. They have established entrepôts at Merv and Pendjeh, which are already supplying the inhabitants of Herat with Russian manufactures and stores.

In America the locomotive carried with it the emigrants who inhabited and cultivated the land. In Asia the locomotive is retracing the paths which the human race trod in its early days, and carries with it all the wonders that the race has gathered up in its long journeyings. This desert was once the garden of the world; but first wars, and then constant incursions of the Turkomans, have devastated it. The character of the Turkomans we learn from Vambéry, who says in one of his books that they " have the well-deserved reputation of sparing nobody, and would even sell the prophet himself into slavery if he should fall into their hands ; " and in another that they have a proverb which says, "If you see a party attacking the house of your father and mother, join them in the plunder and robbery." Now brigandage and slavery have been to a large degree suppressed, and under the Russian rule the old irrigating canals will be re-opened, and this great desert, rich when watered, will be as densely populated as in the early ages. Thus the railroad will become the civilizer of the old world, as it has been of the new. GARDINER G. HubBaRd.

\section{GEOGRAPHICAL NOTES.}

Late news from Alaska. - A weekly newspaper, the Alaskan, has been started at Sitka. It is a neat quarto, and intended to gather information about the territory, and promote its development. It is the fourth newspaper which has actually been printed in Alaska, though several periodicals treating of Alaskan matters have been issued at San Francisco in past years. The Alaska times, a large quarto, edited by T. G. Murphy, appeared in May, 1868, and existed about two years during the military occupation. Some of the numbers were printed on brown paper for want of other material. This was followed in $1875 \mathrm{by}$ a little folio sheet printed on the press of the single military company then left at Sitka, and named the Alaska bulletin. About seven fortnightly numbers appeared; and in October, 1876, a similar issue, under the name of the Sitka post, was begun, and terminated with its fourteenth number, on the final removal of the troops from
Sitka. The present publication is of a more serious character than its predecessors, and the seven numbers which have reached us contain many items of interest which might otherwise have been lost. A weekly summary of the meteorology is furnished by the local signal officer. On the 12th of December, the editor notes that the temperature was stationary at $45^{\circ} \mathrm{F}$., and he received a cabbage, cut that week in one of the local gardens, untouched by frost, and of which the solid head measured about fifteen inches in diameter. A canoe express took the weekly issue from Sitka to Juneau in three days, the distance being about 180 miles. A new town, to be called Edwardsville, was going up near the mines on Douglas Island. The Treadwell mine, though somewhat hampered by a scarcity of water, turned out $\$ 75,000$ in bullion in the last month, and the owners were enlarging its facilities. The Silver Bay mines near Sitka had been taken in hand by a company of capitalists. The oil-works at Killisnoo were running to their utmost capacity, and sent down by the last steamer 300 tons of herringoil. M. E. Hess, writing from Fort Reliance, says that the natives make portages from that place to the Tananah River in eight days. From the head of the latter to the Copper River they go in from four to seven days. The Tananah heads so near the White River that the Tenan Kutchin Indians cross with their furs, and build a raft, on which they descend the White River to the Yukon, and the latter to Fort Reliance, where they trade, thus drifting about four times the direct distance from their homes to the fort. Mr. Hess had concluded to winter on the White River. He reports gold in placers and in quartz in several places, and also what he supposes to be nickel ore. The prospectors on the Lewis River made from $\$ 200$ to $\$ 500$ per man on the bars of that river during the short summer. They report the climate as resembling that of Montana.

The Sakeis of Malay peninsula. - The last annual report of the British resident at Selangore, Malay peninsula, contains some notes on the curious tribe called Sakeis, of whom there are about eight hundred persons. They are divided into nine sections, whose chiefs are called Batins. They live chiefly by collecting rubber and other products of the jungle. They have no formal religion, but are very superstitious, believe in good and bad auguries, consider certain bịds sacred, and abandon any settlement where one of them dies. They tattoo the arms by way of ornament, but the tattooing has no tribal or totemic significance. Nothing capable of being eaten comes amiss to them: even scorpions and snakes are acceptable. They kill game by darts, poisoned 